\title{
Assessment of Undiscovered Oil and Gas Resources of the Illinois Basin, 2007
}

Using a geology-based assessment methodology, the U.S. Geological Survey estimated the following quantities of undiscovered, technically recoverable oil and gas resources in the IIlinois Basin, USA: (1) a mean of 214 million barrels of oil; (2) a mean of 4.65 trillion cubic feet of natural gas; and (3) a mean of 24 million barrels of natural gas liquids.

\section{Introduction}

The U.S. Geological Survey (USGS) has completed an assessment of the undiscovered oil and gas potential of the Illinois Basin (fig. 1). The assessed area includes parts of the States of Illinois, Indiana, Kentucky, Missouri, Ohio, and Tennessee. The assessment is based on the geologic elements of each total petroleum system (TPS) defined in the basin. These geologic elements include the hydrocarbon source rocks, reservoir rocks, and hydrocarbon traps. By using this geologic framework, the USGS defined 4 total petroleum systems and 19 assessment units (AUs) within the basin and estimated the quantity of undiscovered technically recoverable oil and gas resources within 14 of the 19 AUs (table 1).

\section{Total Petroleum Systems}

The four total petroleum systems identified in the Illinois Basin are the (1) Precambrian to Cambrian TPS, (2) Ordovician Ancell/Maquoketa TPS, (3) Devonian to Mississippian New Albany TPS, and (4) Pennsylvanian Coal and Shale TPS. Each TPS is named according to the petroleum source rock(s) of that system. For most of the systems, each TPS is associated with only one source rock. The Precambrian to Cambrian TPS, however, encompasses both source rocks in the Cambrian Eau Claire Formation and older, hypothetical source rocks in the deeper parts of the basin.

\section{Assessment Units}

Sixteen of the AUs are characterized as conventional oil and gas accumulations, and three of the AUs are characterized as continuous accumulations. The 16 conventional AUs are the (1) Pre-

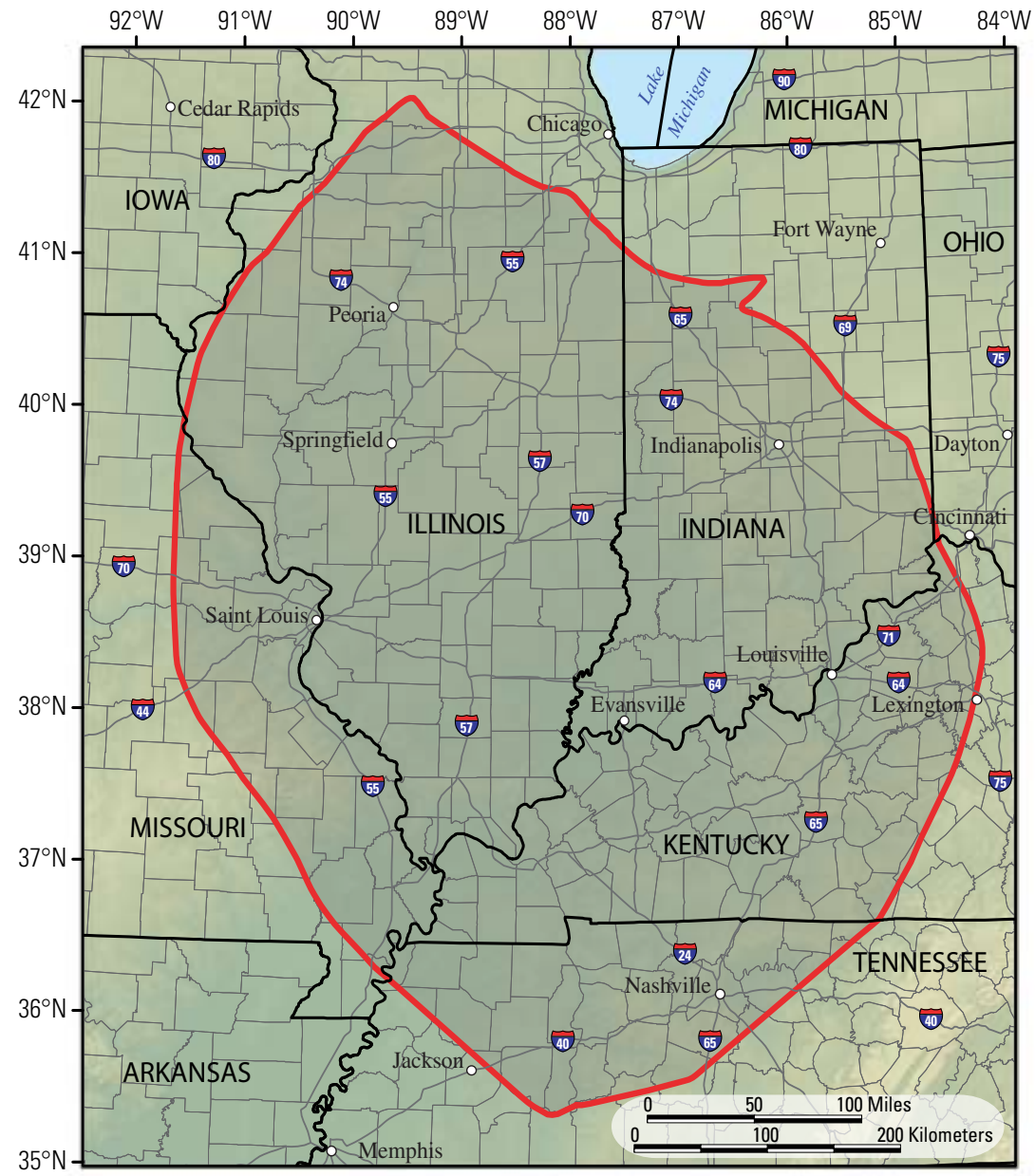

Figure 1. Location of the Illinois Basin (assessed area is within the red boundary).

cambrian to Cambrian Rift-Fill AU, (2) Cambrian Mount Simon to Eau Claire AU, (3) Cambrian to Ordovician Knox Group AU, (4) Cambrian to Ordovician Carbonates Cumberland Saddle AU, (5) Ordovician St. Peter/Everton AU, (6) Ordovician Dutchtown to Galena AU, (7) Lower Silurian Carbonates AU, (8) Upper Silurian Calcareous Siltstones AU, (9) Upper Silurian Carbonates (Reef) AU, (10) Lower Devonian Carbonates AU, (11) Middle Devonian Dutch Creek Sandstone AU, (12) Middle Devonian Carbonates AU, (13) Lower Mississippian Borden AU, (14) Lower Mississippian Carbonates AU, (15) Upper Mississippian Sandstones AU, and (16) Pennsylvanian Sandstones AU. All of these conventional AUs were assessed quantitatively, except for the Precambrian to Cambrian Rift-Fill AU, the Cambrian Mount Simon to Eau Claire AU, the Cambrian to Ordovician Knox Group AU, and the Ordovician St. Peter/Everton AU.

The three continuous AUs are the (1) Ordovician Maquoketa Continuous AU, (2) Devonian to Mississippian New Albany Continuous AU, and (3) Pennsylvanian Coal Bed Gas AU. All of these continuous AUs were assessed quantitatively, except for the Ordovician Maquoketa Continuous AU. 


\section{Resource Summary}

For the Illinois Basin, the USGS estimated the quantities of undiscovered, technically recoverable oil and gas resources as follows (table 1):

(1) a mean of 214 million barrels of oil,

(2) a mean of 4.65 trillion cubic feet of natural gas, and

(3) a mean of 24 million barrels of natural gas liquids.

The Ordovician Dutchtown to Galena AU has the greatest potential for undiscovered oil, with an estimated mean of 72 million barrels of undiscovered, technically recoverable oil. The Upper Silurian Carbonates (Reef) AU and the Middle Devonian Carbonates AU also have substantial potential for undiscovered, technically recover- able oil. The Devonian to Mississippian New Albany Continuous AU has the greatest potential for undiscovered gas, with an estimated mean of 3.79 trillion cubic feet of undiscovered, technically recoverable gas.

\section{Additional Information}

Supporting geologic studies of the Illinois Basin total petroleum systems and assessment units are in progress. Assessment results, as well as information on the assessment methodology, are posted on the USGS web site http://energy.cr.usgs.gov/oilgas/noga as they become available.

\section{Illinois Basin Assessment Team}

Christopher S. Swezey (Task Leader; cswezey@usgs.gov), Joseph R. Hatch, Sean T. Brennan, Joseph A. East, Elisabeth L. Rowan, John E. Repetski, Ronald R. Charpentier, Troy A. Cook, Timothy R. Klett, Richard M. Pollastro, and Christopher J. Schenk.

Table 1. Illinois Basin oil and gas assessment results.

[All tabulated results are for technically recoverable resources. MMBO is million barrels of oil. BCFG is billion cubic feet of gas. MMBNGL is million barrels of natural gas liquids. Results shown are fully risked estimates. For gas accumulations, all liquids are included under the NGL (natural gas liquids) category. F95 represents a 95-percent chance of at least the amount tabulated. Other fractiles are defined similarly. Fractiles are additive under the assumption of perfect positive correlation. TPS is Total Petroleum System. AU is Assessment Unit. CBG is Coal Bed Gas. Gray shade indicates not applicable or not assessed quantitatively]

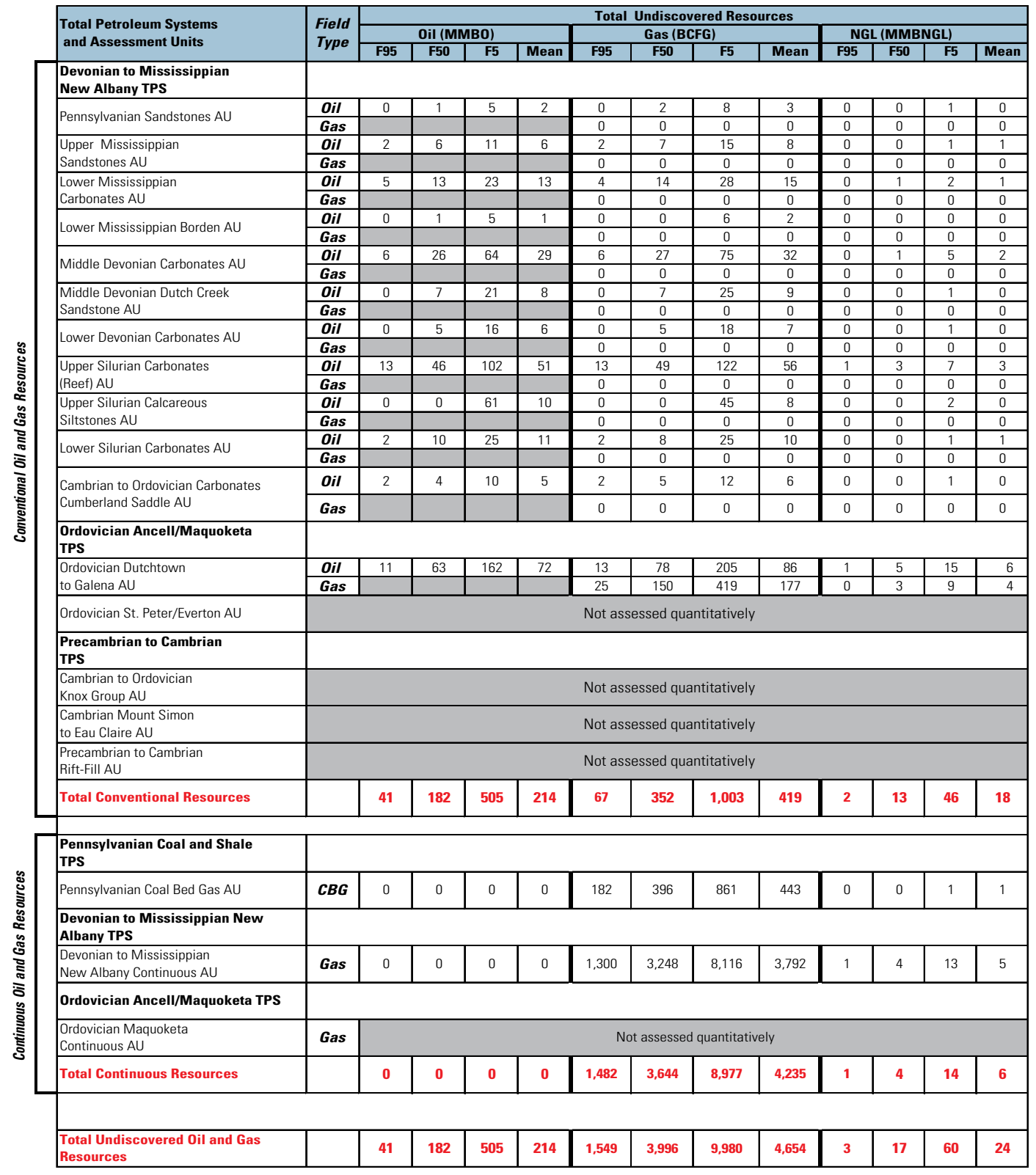

